\title{
12-0-TETRADECANOYLPHORBOL-13-ACETATE INDUCES AN IMMEDIATE, BUT TRANSIENT INCREASE IN MITOTIC ACTIVITY UNCOUPLED FROM DNA SYNTHESIS IN THE MONOLAYER CULTURES OF RAT KERATINOCYTE
}

\author{
Hee-Joong Kim and Isadore A. Bernstein
}

Department of Environmental and Industrial Health and Department of Biological Chemistry. The Lniversity of Michigan, Ann Arbor. Michigan 48109

Received June 16, 1987

A single wave of mitotic activity was observed in a monolaver culture of rat keratinocrtes immediately after exposure to 12-0-tetradecanoylphorbol-13-acetate. A peat for cells in prophase, observed at $10 \mathrm{~min}$ after the exposure. was followed by a peak for metaphase at 20 min. for anaphase at $25 \mathrm{~min}$ and telophase at $30 \mathrm{~min}$ after the exposure. Thereafter. the mitotic activity began $\omega$ subside. This transient stimulation of mitotic activity resulted in an increase of population density in the monolaver culture. There was neither a stimulation of DNA synthesis during this period nor a change of the DNA content after the mitotic activity was completed. This single burst of synchronous mitotic activity which did not require a substantial stimulation of DNA synthesis suggests that the effect was on the initiation process of mitosis among a subpopulation of cells presumably cells delayed in the $G 2$ phase of the cell crcle. $\because 1987$ Academic press, Inc.

A transient hyperplasia without concomitant stimulation of DNA synthesis has been reported from both normal and dimethylbenzanthracene-initiated mouse epidermis after topical exposure to a potent tumor promoter, 12-O-tetradecanoylphorbol-13-acetate (TPA) 11.21. It has been suggested to be a response of a subpopulation normally arrested at the $G 2$ phase of the cell cycle. There is substantial evidence for the existence of a noncycling population in the proliferative compartment of both the epidermis in situ and culture (3-8). Besides postmitotic "maturing" cells, there are "resting" colls which are blocked at different positions in the cell cycle. i.e. $G 1$ and $G \geq$, at the moment but potentially can be recruited into the proliferative pool. Bickenbach and Mackenzie (5) demonstrated in the $\mathrm{C} 3 \mathrm{H}$ mouse epidermis that TPA stimulates a subpopulation of cells which retains incorporated $\left[{ }^{3} \mathrm{H}\right]$ thymidine for extended periods of time to enter mitosis, and suggested that the activation of these slow-cycling cells may play a significant role in tumor promotion. Morris et al. (6) also observed a 16-fold increase in mitotic activity among labelretaining cells as an early response to topical treatment with TPA in SENCAR mouse

Abbreviations: TPA. 12 -0-tetradecanoylphorbol-13-acetate; MEM. minimum essential medium . 
epidermis. It seems conceivable that these "label-retaining" cells are the same cells designated as "G2-arrested" or "G2-delayed" cells elsewhere 1.2.3.7.81.

We have observed an increase in the population density of monolayel cultures of rat keratinocytes grown in low-calcium $(\leq 0.1 \mathrm{mM}$ ! medium shortly after exposure to TPA. Lowering the calcium concentration in growth medium to $\leq 0.1 \mathrm{mM}$ produces a monolarer culture which is similar to the proliferative compartment of the epidermis in many respects $19,10 \mathrm{i}$. To investigate the nature of this prompt and transient hyperplasia induced by TPA, we assayed the dynamics of mitotic activity and the rate of DNA synthesis in parallel. The dynamies of this mitotic activity was monitored by counting the mitotic figures in each phase of the mitotic process separately.

\section{MATERIALS AND METHODS}

\section{Keratinocyte Culture and TPA Exposure}

The culture technique used for newborn rat heratinocytes was as described previously 110 , with several modifications. The dorsal skins were removed from 1-2 day old rats iCFN straini and incubated in $0.25 \%$ crude trypsin (Difcol in PBS containing $1 \%$ glucose for 10 to 12 hours at $4^{\circ} \mathrm{C}$. Epidermis was separated from dermis and the epidermal cells were gently brushed into Eagle's minimum essential medium (MEM! containing $10^{\circ} \mathrm{c}$ fetal calf serum (both from $\mathrm{KC}$ Biological). Basal cells were purified by sedimentation in a density gradient generated from $36 \% \mathrm{c}$ Percoll (Pharmacia Fine Chemicals! in MEM by centrifugation at $30 \mathrm{~K} x \mathrm{~g}$ for $15 \mathrm{~min}$ at $4^{\circ} \mathrm{C}$. Basal cells collected from the lowermost band Density: $\rho>1.075$ ) were resuspended to $5 \times 10^{5}$ cells $/ \mathrm{ml}$ in low-calcium MEM and plated on glass coverslips $(0.2 \mathrm{ml} / 1 \times 22 \mathrm{~mm}$ or $16 \mathrm{~mm}$ multiwell plates $(0.5 \mathrm{ml} /$ well). For low-calcium MIEM. the calcium-free MEN (KC Biological) was supplemented with $10 \%$ Chelex-treated fetal calf serum and the calcium concentration was then raised to $\leq 0.1 \mathrm{mM}$.

TPA (Sigma) was dissolved in acetone $10.1 \mathrm{mg} / \mathrm{ml}$ ) and kept at $-20^{\circ} \mathrm{C}$ in the dark until use. For exposure, the TPA solution was added directly to the culture to a final concentration of $10 \mathrm{ng}$ iml. An equivalent amount of acetone $10.01 \% \mathrm{v}$, was added to the medium of control cultures for parallel experiments.

\section{Selective Staining for Mitotic Figures}

A selective staining technique for mitotic figures introduced by Fraser 11: for paraffin sections of various tissues was used for cultured keratinocytes grown on glass coverslips. This specific technique was developed $t w$ differentiate mitotic cells from resting cells by color. Keratinocyte cultures grown on glass coverslips were fixed in modified Bouin solution for 24 hours. After an overnight rinse with $70 \%$ ethanol the cultures were submitted to hydrolysis in $1 \mathrm{~N}$ $\mathrm{HCl}$ at $60^{\circ} \mathrm{C}$ for $12 \mathrm{~min}$. For the differentiative staining, the cultures were stained for resting cells with $0.1 \%$ Kernechtrot (Roboz Surgical Instrument Co.) in $5 \%$ aluminum sulfate solution for 7 min and followed by staining for mitotic cells with $1 \%$ aqueous crystal violet (Allied Chemical and Dye Co.) for $45 \mathrm{~min}$. Excess dye from each staining was rinsed in an alkaline solution $(0.01 \%$ magnesium carbonate in tap water). After the dehydration with absolute ethanol, the coverslips were mounted on slides with Permount (Fisher Scientific Co.). Selective intense blue staining of mitotic nuclei from early prophase to late telophase was easily identified against the background of resting cells which lightly stained in red.

\section{$I^{3}$ HJThymidine Incorporation and DNA Assay}

DNA was assayed by the method of Setaro and Morley 121. Monolayer cultures were labeled with $1 \mu \mathrm{Ci} / \mathrm{ml}$ of $\left.{ }^{5} \mathrm{H}\right]$ thymidine for 1 hour. After few rinses with ice cold PBS. ice cold $6 c^{\circ}$ TCA was added to the cultured keratinocytes and allowed to stand on ice for $30 \mathrm{~min}$. The TCA precipitate was then incubated with absolute ethanol containing potassium acetate (9.8 g.1) at room temperature fol $10 \mathrm{~min}$. To remove the lipid components from the preparation completely. the cultures were further incubated in absolute ethanol at $60^{\circ} \mathrm{C}$ for $15 \mathrm{~min}$. DNA in each culture was then extracted with $0.1 \mathrm{~N} \mathrm{NaOH}$ at $60^{\circ} \mathrm{C}$ for $20 \mathrm{~min}$. Radioactivity in the DNA was counted 
using a liquid scintillation counter. For the determination of DNA content, an aliquot of $\mathrm{NaOH}$ extracts were dried at $60^{\circ} \mathrm{C}$. A $100 \mu \mathrm{l}$ of diaminobenzoic acid $(200 \mathrm{mg} / \mathrm{ml}$ was added to each dried DNA range 0-2 $\mu \mathrm{g}$ ) samples. After incubation at $60^{\circ} \mathrm{C}$ for $30 \mathrm{~min}$, DNA-diaminobenzoic acid adduct was diluted to $2.0 \mathrm{ml}$ with $1 \mathrm{~N} \mathrm{HCl}$ for fluorometry using fluoroscence spectrophotometer (Model 650-40. Perkin-Elmeri.

\section{RESLLTS AND DISCLSSION}

The cultures of newborn rat keratinocytes grown in low-calcium $\leq 0.1 \mathrm{mMI}$ MEM are maintained as a monolayer and reached confluency by 3 to 4 days (Fig. 1-A. The earliest morphological change in TPA-exposed confluent monolayer cultures was an appearance of a hearier population density (Fig. 1-B). In a typical experiment, we observed a $4 \delta^{\circ}$ c increase in cell number 3 hours after TPA exposure: however, the toral DNA content of the cultures remained the same and the activity of DNA synthesis was reduced significantly (Table 1). Increase in population density observed in TPA-exposed culture was a result of a single wave of mitosis which occurred immediately after the exposure (Fig. 2 ).

TPA-induced mitotic activity was prompt and synchronous and did not require substantial DNA synthesis. A peak in the appearance of cells in prophase was observed as early as $10 \mathrm{~min}$ after the exposure. This was followed by a peak in metaphase after $20 \mathrm{~min}$. a peak in anaphase after $25 \mathrm{~min}$ and finally a peak in telophase after $30 \mathrm{~min}$ (Fig. 2). When the synthesis of DNA was investigated during the perind of the mitotic stimulation by monitoring the $\left[{ }^{3} \mathrm{H}\right]$ thymidine incorporation into cellular DNA. inhibition, rather than stimulation, of DNA synthesis was observed as early as 40 min after TPA exposure (Fig. 3).
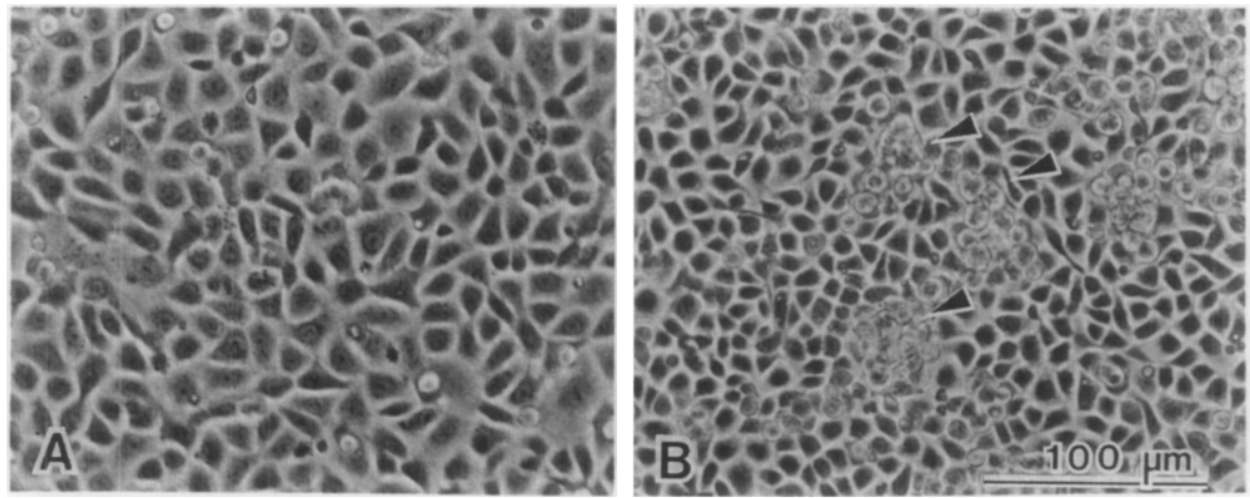

Figure 1. Phase contrast micrograph of monolayer cultures showing morphological changes upon exposure to TPA.

A. a confluent monolayer culture of rat keratinocytes grown for 3 days in low calcium medium. B, 3 hours after the confluent monolayer culture was exposed to $10 \mathrm{ng} / \mathrm{ml}$ TPA showing an increase in population density with larger intercellular space, smaller cell size, and darker cytoplasm. In addition to the increase in population density of the monolayer, more cells are present in the plane above the monolayer (arrow heads). 
Table 1

Details of Early Mitotic Activity in Monolayer Cultures of Rat Keratinocyte Exposed to TPA

\begin{tabular}{lccl}
\hline $\begin{array}{c}\text { Exposure } \\
\text { Time }\end{array}$ & $\begin{array}{c}\text { Population } \\
\text { Density }\end{array}$ & $\begin{array}{c}\text { DNA } \\
\text { Content }\end{array}$ & $\begin{array}{l}{\left[{ }^{3} \mathrm{H}\right] \text { Thymidine }} \\
\text { Incorporation }\end{array}$ \\
\hline $1 \mathrm{hr}$ & $\mathrm{ND}$ & $95.4 \pm 7.57^{* *}$ & $90.7 \pm 3.36$ \\
$3 \mathrm{hr}$ & $148.0 \pm 6.89$ & $97.4 \pm 8.71^{*}$ & $69.5 \pm 14.40$ \\
$5 \mathrm{hr}$ & $\mathrm{ND}$ & $95.0 \pm 2.41^{*}$ & $48.6 \pm 6.19$ \\
$8 \mathrm{hr}$ & $133.4 \pm 11.41$ & $93.8 \pm 8.35^{*}$ & $31.7 \pm 2.68$ \\
\hline
\end{tabular}

ND: Not determined.

Note: Results are expressed as \% of control (mean \pm standard error) assayed in parallel at each time point. There were no significant changes in vehicle control cultures exposed to $0.01 \%$ acetone during the experimental period.

$:$ No significant changes $(p>0.5)$.

Although it is possible that the effect was a result of cell division among normal cycling cells resulting in haploid cells, it seems more reasonable to suggest the $G 2$-delayed cells as possible candidates for this immediate mitogenic activity. The existence of sufficient $G 2$ cells in normal
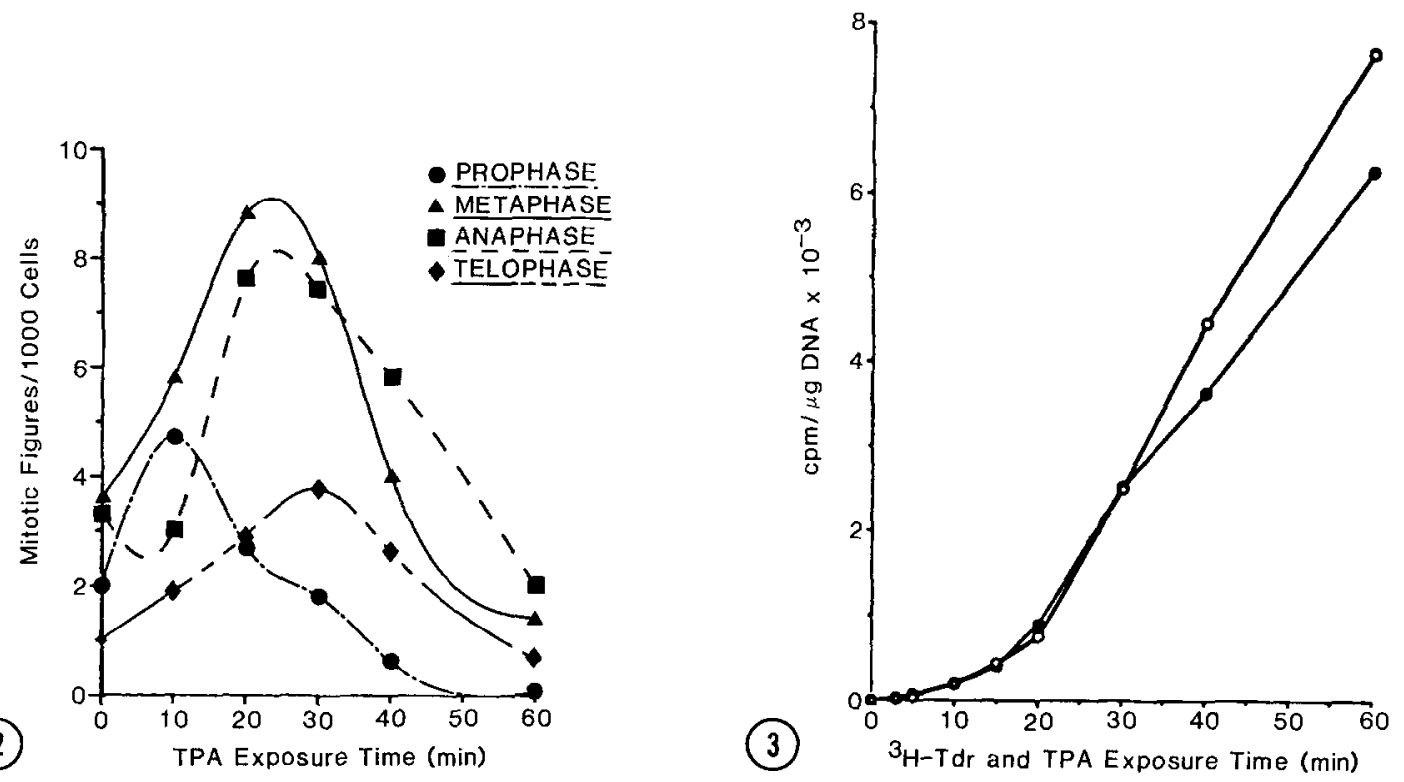

Figure 2. TPA-induced mitotic activity in monolayer cultures of newborn rat keratinocyte.

Time course assay for mitotic figures, performed for each phase of the mitotic process separately, showing a "sweeping out" pattern from prophase to telophase following TPA. exposure. Over 4,000 cells were scored for each time point.

Figure 3. Effect of TPA-exposure on the rate of $\left[{ }^{3} \mathrm{H}\right]$ thymidine incorporation into monolayer cultures of rat keratinocytes.

The rate of DNA synthesis investigated during the period in which TPA stimulates mitosis in monolayer cultures as shown in Figure 2, indicates no concomitant stimulation of DNA synthesis for this mitotic activity. There is no difference in the rate of $\left[{ }^{3} \mathrm{H}\right]$ thymidine incorporation into DNA molecule between control (open circle) and TPA-exposed (solid circle) cultures up to 30 min after exposure. Afterwards, the $\left[{ }^{3} \mathrm{H}\right]$ thymidine incorporation rate begin to reduce. Each point represents the average value from quadruplicate cultures. 
epidermis to yield a $48 \%$ increase in cell number by one division seems unlikely. However, the specific localization of $G 2$ inhibitor in the basal layer has been demonstrated by Elgio et al. $18 \%$. The monolayer culture containing high population of basal cells may have a relatively high concentration of $G 2$ inhibitor. and therefore. a large fraction of cells delared at the $G 2$ phase.

The mechanism of the early mitotic activity induced by TPA-exposure is not known: however. it must have reached maximal activity within $10 \mathrm{~min}$. It has been suggested that most of biological effects of TPA are due to protein kinase $\mathrm{C}$ activation 13\%. TPA and diacylglycerol. both activators of protein kinase $C$. are known to mimic the action of mitogens by rapidly a within a few minutes increasing intracellular $\mathrm{pH}$ and intracellular mobilization of calcium which are two events normally precede cell proliferation 1 14!. Recent information suggests that one of the crucial events for the initiation of mitosis is the hyperphosphorylation of the major structural proteins of the nuclear lamina. lamin A and C. resulting in breakdown of the nuclear envelope (15). Rozengurt et al, :16 have shown that the addition of TPA to quiescent 3 T3 cells results in a rapid (within seconds' phosphorvlation of an $80 \mathrm{~K}$ ccllular protein. This same protein was phosphorylated by addition of some mitogenic peptides. which act through a mechanism of enhanced phosphatidylinositol turnover resulting in an increase of cellular level of diarylgtycerol. Thus it was suggested that a possible role of protein kinase $\mathrm{C}$ in mitogenic activity by phosphorylating this $80 \mathrm{~K}$ protein. Fluctuation in protein kinase $\mathrm{C}$ activity throughout the cell cycle has been demonstrated in PIS endoderm cells 117 . There is a slow. progressive increase in total isoluble plus particulate protein kinase $C$ actirity through the $G 2$ phese, with a more pronounced increase in activity during mitosis. Since protein kinase $\mathrm{C}$ is known to have a broad range of possible endogenous substrates $17 \%$, it is conceivable that protein kinase $C$ actirated by TPA may trigger mitosis in G2-delayed cells by inducing phosphorylation of the proteins that regulate the process of mitosis uncoupled from the ability to stimulate DNA synthesis.

Morris et al. (6) were able to differentiate two subclasses of basal cells in mouse epidermis based on the eary response to TPA-exposure. The label-retaining basal cells entered mitosis while postmitotic "maturing" basal cells migrated more rapidly to the "suprabasal" layers. Shortly after TPA-exposure, we also observed that a large number of cells had migrated to the plane above the monolayer ifig. 1-B!. We have shown in a previous study that the exposure to TPA accelercites the rate and commitment to terminal differentiation of "maturing" basal cells 18. When the monolayer cultures of rat keratinocytes were cxposed to TPA, there was a 
predominent appearance of histidine-rich protein (filaggrin l-positive cells. which is characteristic of granular cells in epidermis in situ. These present observations, together with previous reports 16.18). suggest that the state of individual basal cell in the maturation process may determine the type of response. either entering mitosis or reducing transit time in process of terminal differentiation. upon TPA-exposure.

\section{ACKNOWLEDGEMENTS}

This work was supported in part by grant AMI 07236 from National Institutes of Health. Department of Health and Human Development Services.

\section{REFERENCES}

1. Krieg. L.. Kuhlmarn, I. and Marks. F. 1974; Cancer Res. 34, $3135-3146$.

2. Argris. T.S. 1981, J. Invest. Dermatol. 77. 230-234.

3. Gelfant. S. and Candelas. G.C. 11972 j. Invest. Dermatol. 59. i-12.

4. Filgio. K. Laerum, O.D. and F.dgehill. W, 1971/ Virchows Arch. Abt. B $\delta, 27 \overline{7}-283$.

5. Bickenbach. J.R. and Mackenzie. I.C. (1984) J. Invest. Dermatol. 82, 618-622.

6. Morris, R.J.. Fischer. S.M. and Slaga. T.J. i1985; J. Invest. Dermatol. 84. 277-281.

7. Kitano. Y.. Nagase. N. Okada. N. and Okann, M. 11983; In Normal and Ahnormal Epidermal Differentiation. (M. Seiji and I.A. Bernstein, eds.), pp $9 \bar{i}-108$. Tokyo University Press. Tokyo, Japan.

8. Weinstein, G.D., McCullough, J.L. and Ross, P. (1984/J. Invest. Dermatol. 82. 623-628.

-9. Hennings, H. Michael. D.. Cheng. C.. Steinert, P.. Holbrook. K. and S.H. Yuspa. 1980 , Cell 19. $245-254$.

10. Brown. R.. Kim. H.J., Zha. X.. Kehoe. K.. Mitra. R. S.. Gray. R.H. and Bernstein. I.A. 1987; In Processes in Cutaneous Epidernal Differentiation. II.A. Bernstein and T. Hirone. eds. i pp. 361-385. Praeger Scientific. New York. NY.

11. Fraser. F.J. (1982, Stain Technol. 5744, 219-224.

12. Setaro. F. and Morley, C.G.D. 11976 Analytical Biochem. 71, 313-317.

13. Nishizuka. Y. (1984) Nature 308i19;.693-698.

14. Moolenaar. W.H. Tertoolen. L.G.J. and de Laat. S.W. :1984' Nature 312. 371-374.

15. Miake-Lre. R. and Kirschner. M. IT. 1985: Cell 41. 165-175.

16. Rozengurt. E.. Rodriguez-Pena, M. and Smith. K.A. i1983) Proc. Natl. Acad. Sci. LSA. 80, $7244-7248$.

17. Anderson. IT.B.. Estival. A. Topiovaara. H. and Gopalakrishna. R. (1985) In Advances in Cyclic Nucleotic and Protein Phosphorylation Research.iD.M.F. Cooper and K.B. Seamon. eds.i. Vol. 19, pp. 287-306. Raven Press, New York. NY.

18. Kim. H.J. and Bernstein. I.A. 11987 J. Invest. Dermatol. 88. 624-629. 